DOI https://doi.org/10.32837/app.v0i66.708

УДК 004:35:321.7

T. М. Краснопольська

orcid.org/0000-0001-5936-5889

кандидат політичних наук, доцент,

доцент каредри політичних теоріӥ

Національного університету «Одеська юридична академія»

I. М. Милосердна

orcid.org/0000-0003-2083-9500

кандидат політичних наук, доцент,

доиент кафедри політичних теорій

Національного університету «Одеська юридична академія»

\title{
КОМПОНЕНТИ ЕЛЕКТРОННОЇ ДЕМОКРАТІЇ В УМОВАХ ПЕРЕХОДУ ДО ЕЛЕКТРОННОГО ПРАВЛІННЯ
}

Ефективне управління передбачає взаємний діалог між суспільством і державою. Інтернет та інші інформаційно-комунікаційні технології (далі - IKT) є засобами, які сприяють інтенсифікації такого діалогу. Як зазначає Р. Даль, інститути повинні бути збагачені новими методами, що сприяють розвитку громадянської самосвідомості, участі громадян у політичному житті, отриманню інформації та обговоренню проблем (Даль, 2000, с. 179). Роль IКТ полягає у тому, щоб сприяти залученню громадян у політичні процеси і прийняття державних рішень в рамках відкритого обміну інформацією. Електронна демократія передбачає використання IКТ в демократичному політичному та управлінському процесах.

Відповіддю на тенденції зниження довіри до традиційних інститутів, появу альтернативних моделей політичного інтернет-активізму стало поширення державними структурами онлайн-інструментів участі. Слід зазначити, що надання таких інструментів $є$ показником політичної відкритості влади, тоді як наявність адекватної інформаційної системи слугує критерієм прозорості діяльності органів влади (Rose, 2005).

Перевагою віртуальної комунікації є спрощення механізмів мобілізації та координації, які в перехідних системах стають одним із головних чинників змін. Фактори, що вплинули на розвиток форм політичної участі через мережу Інтернет, можна поділити на мікро- і макрорівні (Походня, 2020). До макрорівня належать глобальні економічні, політичні, соціальні зміни, які несуть у собі модернізацію цінностей, патернів політичної комунікації. Факторами мікрорівня є локальні обставини, які потягли за собою активізацію діяльності у вигляді реакції на ситуаційні зміни. Комплекс розглянутих факторів $є$ каталізатором трансформації форм політичної участі у новому цифровому вимірі.

Як зазначає М. Вершинін, «традиційні уявлення про демократію не можуть бути екстрапольовані на суспільства, які трансформувалися в процесі глобалізації, дигіталізації та постіндустріалізму» (Вершинин, 2002. с. 153). Дійсно, свідомість суспільства, його звички багато в чому зумовлені пануючим суспільним середовищем епохи. Слід погодитися з К. Хілем і Д. Хагом у тому, що «інтернет не змінює людей, він просто дозволяє їм робити те ж саме по-іншому. Всупереч утопічним уявленням інтернет, його розвиток навряд чи перетворять незацікавлених, неінформованих, байдужих громадян у зацікавлених, інформованих і активних кібергромадян» (Hill, Hughes, 1998, с. 157). Отже, електронна демократія стає інструментом громадянського суспільства на шляху до демократизації суспільного життя.

Слід зазначити, що теоретичні та емпіричні засади дослідження електронної демократії заклали Е. Масуда, Дж. Несбіт, П. Ебурдін, Дж. Барбер, С. Коулман, П. Норріс, К. Андерсен, Х. Хенріксен, А. Грёнлунд та інші. Активізація політичної участі, координації та співпраці влади і суспільства з використанням IКТ призвела, на думку Л. Сморгунова, до зміни концептуальної парадигми від електронної держави до електронного правління (Сморгунов, 2007). 
Перше відноситься до міжорганізаційних і внутрішньо-організаційних відносин і характеризується такими поняттями як «електронний уряд» і «електронна адміністрація». Друге (електронне правління) характеризує відносини між громадянами, урядовими структурами, громадською думкою і обраними офіційними особами. Його основними складниками є демократичний процес, відкритий уряд і прозорий механізм прийняття рішень (Benchmarking e-government: A global perspective. Assessing the progress of the UN member states, 2003, p. 54). Таким чином, у суспільстві виникають нові електронні мережеві структури, які пов'язують уряд, громадські асоціації, політичні партії, центри громадської думки і засоби масової інформації.

Дж. Барлоу вважає, що віртуальний простір інтернету є основою якісно іншого суспільства, в якому переможуть дійсна свобода і пряма демократія (Барлоу, 1999). Система електронного правління включає чотири структурних компоненти:

- електронні послуги (e-services), які мають на увазі надання в електронній формі урядової інформації, програм, стратегій і послуг, доступних щодня і цілодобово в режимі онлайн;

- електронне управління (e-management), яке реалізовується через створення єдиної бази даних всередині уряду, що дає можливість керувати даними та інформацією, вести електронні записи і направляти потоки інформації між департаментами;

- електронна демократія (e-democracy), яка представляє собою систему IKT, що розглядається як інструмент у розвитку прямої демократії, тобто передбачає розширення безпосередньої участі громадян у державному управлінні (віртуальні міські збори, публічні наради, телевізійні дебати, опитування громадської думки і громадські форуми в інтернеті);

- електронна комерція (е-commerce), яка створює умови для мобільного і ефективного здійснення громадянами своїх економічних взаємодій із державою (оплата податків, рахунків за житлово-комунальні послуги, реєстрація транспортних засобів) (Целищева, 2011).

Саме електронна демократія, на нашу думку, сприяє активізації політичної участі широких верств громадськості та розвитку прямої демократії. Це особливо актуально на тлі сучасної кризи представницького правління, яка характеризується слабкою легітимністю парламентаризму і сприймається як фасад, що приховує істинний механізм прийняття владних рішень. Так, згідно з дослідженням, проведеним Edelman Trust Barometr, загальний рівень довіри до інститутів влади у світі в 2018 році становив 43\%, у 2019 - 47\%. Мінімальний рівень підтримки отримали не тільки інститути влади, але і бізнес, засоби масової інформації (3МI) та неурядові організації (52\%, 43\% та 53\%). Україна не входить до цього рейтингу. Проте за даними центру Разумкова станом на квітень 2020 року довіру до Президента України висловили 59\% респондентів, Верховної Ради - 28\%, Уряду - 32\%. Такі цифри свідчать про необхідність позитивних змін, які може забезпечити е-демократія.

С. Коулман визначає електронну демократію як взаємодію між державою і громадянами, а також між представниками і тими, кого вони представляють, використовуючи можливості, що надаються цифровими технологіями з метою поліпшення демократичного процесу (Coleman, 2005, c. 8). Про електронну демократію можна говорити на локальному рівні (наприклад, муніципалітетів і місцевого самоврядування), національному та міжнародному рівнях (наприклад, програма Е-Європи 2005). До механізмів електронної демократії відносять:

- електронне голосування;

- $\quad$ колективне обговорення проблем і питань суспільно-політичної тематики в режимі on-line, механізми мережевої комунікації громадян;

- механізми планування та реалізації громадських ініціатив та проектів, а також формування онлайн-спільнот;

- механізми мережевої комунікації громадян з органами влади, включаючи інструменти впливу на прийняття рішень і громадський контроль за діяльністю органів влади;

- механізми громадського онлайн-управління на муніципальному рівні (Лаврик, 2017, с. 72).

Поняття електронної демократії, на думку М. Шустова, включає в себе два компоненти: електронну участь і електронне голосування (Шустов, 2011, с. 275). На думку авторів статті, цей перелік компонентів необхідно доповнити третім - громадським контролем. Умовою ефективності реалізації цих аспектів є громадянська грамотність, під якою слід розуміти су- 
купність здібностей, що дають можливість функціонувати в демократичному суспільстві, критично мислити, діяти обдумано в умовах плюралізму (Башкарев, 2008, с. 27.).

Слід зазначити, що світова практика має напрацювання по всіх трьох напрямах електронної демократії. Так, електронне голосування вперше було використано на місцевих виборах в Естонії у 2005 році. На виборах 2015 року такою процедурою скористалося 30\% виборців (Как создается и работает электронная демократия, 2018). Система електронного голосування активно використовується в США та запроваджується в країнах $Є С$, на рівні самого союзу.

Електронна участь означає комплекс методів та інструментів, які забезпечують електронну взаємодію громадян і органів влади з метою врахування думки громадян у державному і муніципальному управліннях, при прийнятті політичних рішень, включаючи реагування на звернення громадян 3 широкого кола проблем. Слід підкреслити, що електронну взаємодію не потрібно зводити виключно до використання інтернет-технологій (Чугунов, 2017, с. 15).

Електронна участь отримала поширення в багатьох країнах світу. Наприклад, в Естонії уряд заохочував таку участь за допомогою проекту Estonian E-Citizen, в рамках якого створено два електронних ресурси: Citizen Portal i Information Portal, якими управляє Департамент державної інформаційної системи Естонії. Портали відкривають двері в електронну державу, інформуючи громадян про їхні права та обов'язки, а також надаючи доступ до баз даних, електронних послуг, віртуального офісу (Штепа, 2016). 2014 року в Естонії було запроваджено правило, відповідно до якого парламент зобов' язаний розглядати звернення громадян, під яким підписалися понад 1000 осіб (на базі платформи Rahvaalgatus.ee). У результаті за чотири роки 16 таких звернень пройшли до парламенту, а два з них стали законами.

У Новій Зеландії при перегляді закону про поліцію, який діяв з 1958 року, у 2007 році увазі громадськості була представлена електронна версія нового законопроекту. В результаті експерименту через IКТ були отримані і враховані 234 пропозиції, які лягли в основу нового документа. На думку експертів, участь громадян стала одним із основних аспектів у процесі підготовки цього закону (Лаврик, 2017, с. 70).

Ісландія пішла ще далі - тут було організовано обговорення проекту конституції з використанням соціальних мереж Фейсбук, Твіттер, YouTube i Flickr. У результаті до Конституційної ради надійшло понад 300 офіційних пропозицій і 3600 коментарів, які були враховані при підготовці проекту документа. Нова конституція розширила повноваження місцевої влади, громадяни отримали право анулювати закони, прийняті парламентом, і вносити закони на розгляд: 10\% виборців можуть зажадати проведення всенародного референдуму щодо скасування закону, прийнятого парламентом, $2 \%$ - запропонувати розглянути проект нового закону (Как создается и работает электронная демократия, 2018).

В сучасних умовах при наявності загроз прямої демократії з більшою актуальністю постає питання про необхідність прямого контролю інформаційного простору. Поширення IKT створює реальну можливість залучення у процес прийняття значущих політичних рішень практично усіх активних громадян, створює умови для справжнього та ефективного громадського контролю за діяльністю державних і муніципальних органів влади.

Нині громадський контроль активно реалізується за допомогою технологій електронної демократії. Так, на сайті столиці Швеції Стокгольма є підписка на цікаву для громадян інформацію, в тому числі протоколи засідань, результати розслідувань. Також там можна відстежити долю звернення до уряду від моменту його надходження до адміністрації до прийняття остаточного рішення. В Амстердамі (столиці Нідерландів) створена безкоштовна інформаційна служба Amsterdam Mail, яка розсилає жителям міста електронні повідомлення з потрібних тем.

Особливістю електронної демократії Великобританії є орієнтованість на кожного користувача та спроба зрозуміти його потреби і забезпечити тісну взаємодію влади та суспільства (Government Digital Strategy, 2013). В країні здійснюється пристосування інтернет-сервісів до потреб недосвідчених користувачів, щоб до державних послуг могли звернутися навіть ті громадяни, які раніше не користувалися мережею Інтернет.

Однак електронна демократія пов'язана і з певними ризиками та небезпеками. Так, М. Вершинін вказує на такі з них: 
- небезпека маніпулювання даними голосувань і виборів через відсутність достатнього захисту даних;

- небезпека поділу суспільства на тих, хто володіє інформацією, і тих, хто не володіє нею (цифровий поділ), обмеження принципу демократії вибору;

- $\quad$ небезпека пропаганди злочинних та екстремістських угруповань та їх вплив, особливо на молоде покоління (Вершинин, 2004).

Для подолання таких ризиків кожна держава має розвивати усі три компоненти е-демократії. Л. Бершадська, А. Біккулов та А. Чугунов вважають, що перспективи розвитку електронного урядування та електронної демократії пов' язані з діяльністю, яка здійснюється в таких напрямах:

- поступовий перехід на електронну взаємодію;

- розвиток громадських ініціатив та краудсорсінгових проектів, заснованих на активності громадян у соціальних мережах;

- інституціоналізація статусу електронного обігу («електронної петиції) громадянина як обов' язкового для розгляду органами влади після проходження певної процедури і організації відкритого голосування в інтернеті (Бершадская, Биккулов, Чугунов, 2013).

На нашу думку, цей перелік слід доповнити розширенням можливостей для громадського контролю за діяльністю органів влади та управління. Головна мета електронної демократії на світовій арені полягає не в тому, щоб змусити громадян користуватися інформаційними технологіями - вона полягає у використанні технологій з метою поліпшення участі та демократичного управління.

Варто зазначити, що неодмінною умовою успішної та ефективної модернізації сучасної України є реалізація концепту електронної демократії, яка має стати інформаційно-технологічним базисом для демократизації політичної системи і підвищення самосвідомості громадян як активних учасників суспільно-політичних комунікацій з державою. Проте на цьому етапі існує низка серйозних перешкод на шляху до успішної реалізації державних програм дигіталізації управління в Україні.

Електронна демократія сприяє розвитку інклюзивної політичної системи, за якої населення може бути включене в політичне життя за допомогою різних форм політичної участі. Це позначається і на консолідації суспільства - різні спільноти з легкістю поширюють свої ідеї, знаходять прихильників і однодумців. У результаті формується дієве громадянське суспільство.

Слід наголосити, що запровадження електронної демократії буде ефективним тільки в разі забезпечення високого рівня електронної участі та громадського контролю. На наш погляд, механізми електронної демократії на місцевому рівні виконують як мінімум дві функції: забезпечують постійний і відкритий діалог влади і суспільства, а також мотивують суспільство з активною громадянською позицією.

Основний сенс електронної демократизації полягає у використанні ІКТ в цілях розширення доступу виборців і представників 3МІ до законотворчої діяльності, зниження витрат по формуванню асоціацій і об'єднань виборців, підвищення ефективності зворотних зв'язків між виборцями та їхніми представниками в законодавчих органах влади. Таким чином, впровадження електронної демократії дає змогу вдосконалювати систему волевиявлення і підвищувати політичну участь кожного члена суспільства у випадках раціонального функціонування тієї чи іншої політичної системи.

\section{Лimepamypa}

Барлоу Дж. Декларация независимости киберпространства. Интернет-журнал «Эйдос». 1999. 20 декабря. URL: http:/ /www.eidos.ru/journal/1999/1220.

Башкарев А.А. Электронная демократия как форма политической коммуникации. Известия РГПУ им. А.И. Гериена. 2008. № 69. С. 25-29. URL: https:// cyberleninka.ru/article/n/elektronnaya-demokratiya-kakforma-politicheskoy-kommunikatsii.

Бершадская Л.А., Биккулов А.С., Чугунов А.В. Дискуссии в социальных медиа и электронная демократия: развитие исследовательского инструментария. Политическая экспертиза: ПОЛИТЭКС. 2013. Т. 9, № 2. С. 230-241.

Вершинин М.С. Политическая коммуникация в информационном обществе: перспективные направления исследований. Актуальные проблемы теории коммуникации .СПб : Изд-во СПбГПУ, 2004. С. 98-107. 
Вершинин М.С. Электронная демократия как компьютерно-опосредованная форма политической коммуникации. Коммуникация: теория и практика в различных социальных контекстах : материалы Международной научно-практической конферениии «Коммуникаиия-2002». Ч. 1. Пятигорск, 2002. С. $153-155$.

Даль Р. О демократии. М. : Аспект Пресс, 2000.

Как создается и работает электронная демократия. 2018. ИЦ Региональные системы. URL: https:/ / www.ec-rs.ru/blog/novosti/kak-sozdaetsya-i-rabotaet-elektronnaya-demokratiya/.

Лаврик Н.В. Электронная демократия: мировой опыт. Вестник ЗабГУ. 2017. Т. 23. № 2. С. 67-74.

Оцінка громадянами ситуації в країні, рівень довіри до соціальних інститутів та політиків, електоральні орієнтації громадян (квітень 2020 року, соціологія). Центр Разумкова. URL: https://razumkov. org.ua/napriamky/sotsiologichni-doslidzhennia/otsinka-gromadianamy-sytuatsii-v-kraini-riven-dovirydo-sotsialnykh-instytutiv-ta-politykiv-elektoralni-oriientatsii-gromadian-kviten-2020r.

Походня А.В. Генезис и факторы политического интернет-активизма. Общество: политика, экономикa, право. 2020. № 7(84). URL: https:// cyberleninka.ru/article/n/genezis-i-faktory-politicheskogo-internetaktivizma.

Сморгунов Л.В. От электронного государства к электронному правлению: смена парадигмы. Полит. наука. 2007. № 4. URL: https://cyberleninka.ru/article/n/ot-elektronnogo-gosudarstva-k-elektronnomupravleniyu-smena-paradigmy.

Целищева Е.Ф. От электронного правительства к электронному государству. ЭГО: Экономика. Государство. Общество. 2011. Вып. № 2(6): Новое гос. управление: реформы в условиях модернизации. URL: http://ego.uapa.ru/issue/2011/02/01/.

Чугунов А.В. Электронное участие в контексте трансформации концепции демократии. Управленческое консультирование. 2017. № 8. С. 14-20.

Штепа В. «Э-государство»: почему Эстония победила в рейтинге посткоммунистических демократий. 2016. Forbes.ru. URL: http://www.forbes.ru/mneniya/mir/326255-e-gosudarstvo-pochemu-estoniyapobedila-v-reitinge-postkommunisticheskikh-demokra.

Шустова М.С. К вопросу внедрения электронного правительства и электронной демократии в Европе. Общество и право. 2011. № 2(34). С. 273-276.

Edelman Trust Barometer: Global Report. Edelman Trust Barometr. URL: https:/ /www.edelman.com/sites/g/ files/aatuss191/files/2018-10/2018_Edelman_Trust_Barometer_Global_Report_FEB.pdf.

Edelman_Trust_Barometer_Global_Report. Edelman Trust Barometr. URL: https://www.edelman.com/ sites/g/files/aatuss191/files/2019-02/2019_Edelman_Trust_Barometer_Global_Report.pdf.

Benchmarking e-government: a global perspective. Assessing the progress of the UN member states. N.-Y : UN-DPEPA, APSA, 2003.

Coleman S. Direct representation, towards a conversational democracy. London : IPPR, 2005.

Government Digital Strategy. 2013. GOV.UK. URL: https://www.gov.uk/government/publications/ government-digital-strategy.

Hill K.A., Hughes J.E. Cyberpolitics: Citizen Activism in the Age of the Internet. Oxford, UK : Rowman and Littlefield Publishers Inc., 1998.

Rose R.A Global diffusion model of e-governance. Journal of public policy. Cambridge : Cambridge university press, 2005. № 25. P. 5-27.

\section{References}

Edelman Trust Barometer: Global Report. Edelman Trust Barometr. URL: https:/ /www.edelman.com/sites/g/ files/aatuss191/files/2018-10/2018_Edelman_Trust_Barometer_Global_Report_FEB.pdf [in Ebglish].

Edelman_Trust_Barometer_Global_Report. Edelman Trust Barometr. URL: https://www.edelman.com/ sites/g/files/aatuss191/files/2019-02/2019_Edelman_Trust_Barometer_Global_Report.pdf [in Ebglish].

Barlou Dzh. Deklaratsiya nezavisimosti kiberprostranstva [Declaration of Independence of Cyberspace]. Internet-zhurnal "Eydos" [Internet magazine "Eidos"]. 1999, 20 dekabrya. URL: http://www.eidos.ru/ journal/1999/1220 [in Russian].

Bashkarev A.A. Elektronnaya demokratiya kak forma politicheskoy kommunikatsii [Electronic democracy as a form of political communication]. Izvestiya RGPU im. A.I. Gertsena [Izvestia RGPU im. A.I. Herzen]. 2008. № 69. S. 25-29. URL: https:/ / cyberleninka.ru/article/n/elektronnaya-demokratiya-kak-forma-politicheskoykommunikatsii [in Russian].

Benchmarking e-government: a global perspective. Assessing the progress of the UN member states. N.-Y : UN-DPEPA, APSA, 2003 [in Ebglish].

Bershadskaya L.A., Bikkulov A.S., Chugunov A.V. Diskussii v sotsialnykh media i elektronnaya demokratiya: razvitiye issledovatelskogo instrumentariya [Discussions in social media and e-democracy: development of research tools]. Politicheskaya ekspertiza: POLITEKS [Political Expertise: POLITEX]. 2013. T. 9. № 2. S. 230-241 [in Russian]. 
Chugunov A.V. Elektronnoye uchastiye $\mathrm{v}$ kontekste transformatsii kontseptsii demokratii [Electronic participation in the context of the transformation of the concept of democracy]. Upravlencheskoye konsultirovaniye [Management consulting]. 2017. № 8. S. 14-20 [in Russian].

Coleman S. Direct representation, towards a conversational democracy. London : IPPR, 2005 [in Ebglish].

Dal R. O demokratii [Electronic democracy as a computer-mediated form of political communication]. M. : Aspekt Press. 2000 [in Russian].

Government Digital Strategy. 2013. GOV.UK. URL: https://www.gov.uk/government/publications/ government-digital-strategy [in Ebglish].

Hill K.A., Hughes J.E. Cyberpolitics: Citizen Activism in the Age of the Internet. Oxford, UK : Rowman and Littlefield Publishers Inc., 1998 [in Ebglish].

Kak sozdayetsya i rabotayet elektronnaya demokratiya [How e-democracy is created and works]. 2018. ITs Regionalnyye sistemy [IC Regional systems]. URL: https://www.ec-rs.ru/blog/novosti/kak-sozdaetsyai-rabotaet-elektronnaya-demokratiya/ [in Russian].

Lavrik N.V. Elektronnaya demokratiya: mirovoy opyt [Electronic Democracy: World Experience]. Vestnik ZabGU [ZabGU Bulletin.]. 2017. T. 23. № 2. S. 67-74 [in Russian].

Ocinka gromadyanamy sytuaciyi $\mathrm{v}$ krayini, riven doviry do socialnyx instytutiv ta politykiv, elektoralni oriyentaciyi gromadyan (kviten $2020 \mathrm{r}$., sociologiya) [Citizens assessment of the situation in the country, the level of trust in social institutions and politicians, electoral orientations of citizens (April 2020, sociology)]. Centr Razumkova [Razumkov Center]. URL: https://razumkov.org.ua/napriamky/sotsiologichni-doslidzhennia/ otsinka-gromadianamy-sytuatsii-v-kraini-riven-doviry-do-sotsialnykh-instytutiv-ta-politykiv-elektoralnioriientatsii-gromadian-kviten-2020r [in Ukrainian].

Pokhodnya A.V. Genezis i faktory politicheskogo internet-aktivizma [Genesis and factors of political Internet activism]. Obshchestvo: politika. ekonomika. Pravo [Society: politics, economics, law]. 2020. № 7(84). URL: https:/ / cyberleninka.ru/article/n/genezis-i-faktory-politicheskogo-internet-aktivizma [in Russian].

Rose R. A Global diffusion model of e-governance. Journal of public policy. Cambridge : Cambridge university press, 2005. № 25. P. 5-27 [in Ebglish].

Shtepa V. "E-gosudarstvo": pochemu Estoniya pobedila v reytinge postkommunisticheskikh demokratiy ["E-state": why Estonia has won the rating of post-communist democracies]. 2016. Forbes.ru. URL: http:// www.forbes.ru/mneniya/mir/326255-e-gosudarstvo-pochemu-estoniya-pobedila-v-reitingepostkommunisticheskikh-demokra [in Russian].

Shustova M.S. K voprosu vnedreniya elektronnogo pravitelstva i elektronnoy demokratii v Evrope [On the issue of introducing e-government and e-democracy in Europe]. Obshchestvo i pravo [Society and law]. 2011. № 2(34). S. 273-276 [in Russian].

Smorgunov L.V. Ot elektronnogo gosudarstva k elektronnomu pravleniyu: smena paradigm [From e-government to e-government: a paradigm shift]. Polit. Nauka [Polit. the science]. 2007. № 4. URL: https:/ / cyberleninka.ru/ article/n/ot-elektronnogo-gosudarstva-k-elektronnomu-pravleniyu-smena-paradigmy [in Russian].

Tselishcheva E.F. Ot elektronnogo pravitelstva k elektronnomu gosudarstvu [From e-government to e-state.]. EGO: Ekonomika. Gosudarstvo. Obshchestvo [EGO: Economics. State. Society]. 2011. Vyp. № 2(6): Novoye gos. upravleniye: reformy $\mathrm{v}$ usloviyakh modernizatsii [New state. management: reforms in the context of modernization]. URL: http://ego.uapa.ru/issue/2011/02/01/ [in Russian].

Vershinin M.S. Politicheskaya kommunikatsiya v informatsionnom obshchestve: perspektivnyye napravleniya issledovaniy [Political communication in the information society: perspective directions of research]. Aktualnyye problemy teorii kommunikatsii [Actual problems of the theory of communication]. SPb : Izd-vo SPbGPU. 2004. C. 98-107 [in Russian].

Vershinin M.S. Elektronnaya demokratiya kak kompyuterno-oposredovannaya forma politicheskoy kommunikatsii [Electronic democracy as a computer-mediated form of political communication]. Kommunikatsiya: teoriya i praktika $v$ razlichnykh sotsialnykh kontekstakh : materialy mezhdunarodnoy nauchnoprakticheskoy konferentsii "Kommunikatsiya-2002" [Communication: theory and practice in various social contexts : materials of the international scientific-practical conference "Communication-2002"]. Ch. 1. Pyatigorsk, 2002. S. 153-155 [in Russian].

\section{Анотація}

Краснопольська T. М., Милосердна I. М. Компоненти електронної демократії в умовах переходу до електронного правління. - Стаття.

У статті розглянуто сутність і роль електронної демократії в сучасному світі в умовах зміни парадигми від електронної держави та електронного правління. Встановлено, що перше відноситься до міжорганізаційних і внутрішньо-організаційних відносин і характеризується такими поняттями як «електронний уряд» $\mathrm{i}$ «електронна адміністрація», а друге (електронне правління) характеризує відносини між громадянами, урядовими структурами, громадською думкою і обраними офіційними особами. 
Встановлено, що про електронну демократію можна говорити на локальному рівні (наприклад, муніципалітетів і місцевого самоврядування), національному та міжнародному рівнях (наприклад, програма Е-Свропи 2005). Визначено три основні компоненти електронної демократії: електронне голосування, електронна участь та громадський контроль за допомогою IКТ. Проаналізовано особливості кожного з них, а також світову практику їх застосування. Визначено, що умовою ефективності реалізації усіх компонентів електронної демократії є громадянська грамотність (сукупність здібностей, які дають можливість функціонувати в демократичному суспільстві, критично мислити, діяти обдумано в умовах плюралізму).

3'ясовано основні ризики формування та реалізації, а також перспективи розвитку електронної демократії в сучасному світі. До останніх віднесені поступовий перехід на електронну взаємодію; розвиток громадських ініціатив та краудсорсінгових проектів, заснованих на активності громадян у соціальних мережах; інституціоналізація статусу електронного обігу («електронної петиції»); розширення можливостей для громадського контролю за діяльністю органів влади та управління. Обгрунтовано необхідність становлення основних компонентів е-демократії в Україні.

Ключові слова: електронна демократія, електронне правління, електронна участь, електронне голосування, інформаційно-комунікаційні технології.

\section{Summary}

Krasnopolska T. M., Myloserdna I. M. Components of e-democracy in the transition to e-government. Article.

The article considers the essence and role of e-democracy in the modern world in the conditions of paradigm shift from e-state and e-government. It is established that the first refers to inter-organizational and internal-organizational relations and is characterized by such concepts as "e-government" and "e-government" and the second (e-government) characterizes relations between citizens, government agencies, public opinion and elected officials. It has been established that e-democracy can be discussed at the local level (for example, municipalities and local self-government), nationally and internationally (for example, the E-Europe program 2005).

Three main components of e-democracy have been identified: e-voting, e-participation and public control through ICT. The peculiarities of each of them, as well as the world practice of its application are analyzed. It is determined that the condition for the effective implementation of all components of e-democracy is civic literacy (a set of abilities that allow to function in a democratic society, to think critically, to act thoughtfully in a pluralistic environment). The main risks of formation and implementation, as well as prospects for the development of e-democracy in the modern world are clarified.

The latter include: a gradual transition to electronic interaction; development of public initiatives and crowdsourcing projects based on the activity of citizens in social networks; institutionalization of the status of electronic circulation ("electronic petition"); expanding opportunities for public control over the activities of government and administration. The necessity of formation of the main components of e-democracy in Ukraine is substantiated.

Key words: e-democracy, e-government, e-participation, e-voting, information and communication technologies. 